\title{
Copper Measurement
}

National Cancer Institute

\section{Source}

National Cancer Institute. Copper Measurement. NCI Thesaurus. Code C111161.

The determination of the amount of copper present in a sample. 